\title{
Література:
}

1. Щодо завершення 2019/20 навчального року / Лист МОН України № 1/9-178 від 27.03.2020 p. URL: https://mon.gov.ua/ua/npa/shodozavershennya-201920-navchalnogo-roku /.

2. Рекомендації щодо організації поточного , семестрового контролю та атестації здобувачів фахової та перед-вищої та вищої освіти із застосуванням дистанційних технологій навчання . / Лист МОН України № 1/9-249 від 14.05.2020 p. URL: https://mon.gov.ua/ua/npa/shodoorganizaciyi-potochnogo-semestrovogo-kontrolyu-ta-atestaciyi-zdobuvacchivosviti-izzastosuvannyam-distancijnih-tehnologij.

3. Кухаренко В.М. Проблеми дистанційного навчання 20212 січня 2021 p. URL: https://kvn-e-learning.blogspot.com/2021/01/2021.html

DOI https://doi.org/10.30525/978-9934-26-110-7-87

\section{FORMING THE POSITIVE MOTIVATION OF THE FIRST-YEAR STUDENTS OF A PEDAGOGICAL UNIVERSITY TO STUDYING THE ENGLISH LANGUAGE}

\author{
Shramko R. H. \\ Candidate of Philological Sciences, \\ Associate Professor at the Department of English and German Philology \\ Poltava V. G. Korolenko National Pedagogical University \\ Rakhno M. Yu. \\ Candidate of Philological Sciences, \\ Associate Professor at the Department of English and German Philology \\ Poltava V. G. Korolenko National Pedagogical University \\ Poltava, Ukraine
}

The modern human-centred scientific paradigm is focused, beside other things, on the speaker as a bearer of the native language (L1) sociolinguistic matrix and the communicant willing to acquire the linguocultural code of the foreign language (L2) - in the context of this paper, the English language. Communicative approach is capable of showing the maximum efficiency under these conditions by ensuring individualized approach to each first-year student and allowing to form full-fledged subject-subject relations in the early period of studies and to empower them during the further periods. Such 
relations provide the groundwork for successful implementation of systemic language practice in all four major linguistic skills, as «It is when and where the person really masters [...] skills and components of communicative competence necessary for real interaction» [3, p. 125].

Using subject-subject communication is aimed at creating a full-blown English-speaking environment which shall help the first-year student to adapt to new challenges and realities and to facilitate breaking the language barrier. The communicative method based on the Oxford and Cambridge approaches to teaching EFL, has an aim of introducing the student to the language processes as much as possible [2]. At the same time, the differentiated interaction takes the first-year student's world-view system and personal identification into account. In the long run, it is going to stimulate their cognitive abilities and develop their creative interests and cognitive activity [1, p. 93-94].

Successful use of the above-mentioned methodology and setting the productive subject-subject interaction are impossible without creating and maintaining the student's positive motivation towards learning EFL. That is why the main communicative aim of the EFL teacher at the initial stage is creating rapport and positive co-operation with the student.

The educational activities of the first-year philology students of Poltava V. G. Korolenko National Pedagogical University within the framework of the course «Practice of Oral and Written English» are aimed at mastering the content modules «Me and My Family», «University Life and the Prospects», «Seasons and Weather», «Food», «Shops and Services».

Module 1 of the first semester allows both the teacher and the student to create a self-presentation in an arbitrary unconstrained way. In this presentation the student gives an overview of their family dynamics, their location, preferences and the most important life values. Setting a positive atmosphere in a mini-group is further facilitated by discussion questions, e.g. What is your brightest memory of spending time together with your family? What are the strongest features of your family? What makes your relations stronger? Which family traditions would you like to share with your new group mates? Which positive experience (skills) have you got from your family for your future adult life? What are you grateful for to your parents? for the sub-topic My Family. During the communication in the sub-topic Where I Am Living positive rapport in the mini-group is formed by the following discussion points: Which local places do you consider most interesting / attractive for tourists and why? Would you like to see your place on the tourist world map? Which place in your home do you associate with creative freedom? What in your home makes 
you creative, inspires you? Do you have any things (photos) in your house that you can call the results of your inspiration?

Studying the content module University Life and Prospects can be started with a team task University as a Way for Success in My Life where each participant offers their view of the university on their road to personal success. This communicative task consolidates the mini-group and simultaneously allows to concentrate on the positive role of the university in the life of a young person, to accentuate the prospects for everyone. One more advantage of this exercise is that it is oriented to the future communication with native English speakers within the framework of the chosen major which is going to empower the first-year student's newly-acquired positive motivation.

In the content module Seasons and Weather (Semester 2) fostering the positive motivation can be accomplished with the help of discussion points such as Which weather is the most typical for your location (the location of your alma-mater?) What are the advantages of each season? Which weather is the most favourable for growing vegetables (fruits, grains, etc.)? What is your personal positive experience with certain types of weather? Such questions both provide the students with comparative analysis skills and allow them to reflect on personal impressions from experiencing a certain atmospheric phenomenon.

Mastering the content module Food and Meals can be achieved through such questions: Which foods (meals) make you feel good / inspired? Which meals do you associate with your best memories? Which food would you recommend to your groupmates as those contributing to vivacity and long life? What are the advantages of healthy eating nowadays?

In the content module Shops and Services positive rapport is formed by the questions: When did you enjoy buying anything on your own for the first time? Which things (products, services) do you like to buy most of all? Which way of shopping (direct or on-line) do you prefer (and what advantages does it offer?) Which useful shopping tips would you like to share with your group?

It should be noted that the above-mentioned questions appeal to the speaker's positive experience in each of the life situations, that is why they can be paraphrased using one of the patters: Have you ever tried..? Was your experience positive? What was the most successful way to gain (get) it? It gives the opportunity to concentrate the communicants' attention of the advantages of a certain phenomenon, with the collective discussion facilitating the improvement of language skills.

Apart from self-presentations and group projects, active pair-work empowers the positive motivations of the first-year students (Imagine that you as a fashion expert are helping your peer to choose the best clothing options 
for...; Recommend a foreigner the best places to visit in your location and set the best route; Ask a famous chef for tips on healthy eating and an authentic British cuisine recipe; Take an interview from a professional EnglishUkrainian interpreter and ask for useful tips on improving business (academic) writing / oral simultaneous translation, speaking articulation, etc.). These activities can be done during the lesson or given as a pair project. Improving grammar skills and attention can be done through cross listening (one pair of students is answering, another one is listening to give feedback on accuracy), game situations (a thematic tongue-twister competition; proverbs using the names of fruits (vegetables, dishes, etc.), project work in a minigroup on creating a portfolio (dishes with etymology notes attached / a chef's profile, etc.), creative tasks (a mock trial over junk food, etc.), creating and doing lesson-related puzzles.

Thus, forming and maintaining the positive motivation is an indispensable pre-requisite of mastering a foreign (English) language, a weighty incentive to acquire the professional skills and a pledge of the first-year student's future personal success.

\section{References:}

1. Козак М. В. Комунікативний метод навчання іноземних мов. Науковий вісник Ужгородського наиіонального університету. Серія «Педагогіка, сочіальна робота». 2014. Вип. 32. С. 93-95.

2. Комунікативний підхід при вивченні англійської мови. URL: http://interconf.fl.kpi.ua/node/1184 (дата звернення: 05.07.2021)

3. Тарнопольський О. Б. Методика викладання іноземних мов у вищій школі : підручник для студ. мовних спец. закладів вищої освіти / О. Б. Тарнопольський, М. Р. Кабанова ; ред. С. І. Мазур. Вінниця : Нова Книга, 2020. 384 с. 